\title{
Teaching a Language in Another Modality: A Case Study from Swedish Sign Language L2 Instruction
}

\author{
Ingela Holmström \\ Department of Linguistics, Stockholm University, Sweden
}

\begin{abstract}
This study focuses on a Swedish Sign Language (STS) interpreting education, in which the students learn a second language (L2) that is expressed in the visual-gestural modality instead of the auditory-vocal one. Due to the lack of research on sign language $L 2$ instruction, the teachers have limited scientific knowledge and proven experience to lean on in their work. Therefore, an action research-based project was started with the aim to enhance teachers' knowledge about effective ways of teaching STS as an L2, and to examine how teaching can lead to students making good progress and attaining deep knowledge in STS. The article presents results from one of the projects' sub-studies, Initial teaching through different primary languages, where a hearing STS L2 teacher's approaches are examined when teaching the hearing students the new language in another modality than their previous language(s). The results show how this teacher uses her own knowledge from learning STS as an L2 and how she, through using spoken Swedish, provides rich metalinguistic knowledge that contributes to the students' deeper theoretic knowledge about STS in addition to their practical STS learning. This had pedagogical implications for the further development of the instruction at the interpreting program.
\end{abstract}

Index Terms — sign language, second modality, second language, language instruction, second language teacher

\section{INTRODUCTION}

In Sweden, sign language interpreter training has been offered since 1986 when the Institute for Interpreting and Translation Studies was established (Almqvist, 2013). This training has mainly been conducted in Swedish folk high schools, ${ }^{1}$ but in 2013, the first interpreter training at university level was offered at Stockholm University. This education is now well established and is today offered in parallel with the three folk high schools that still have Swedish Sign Language (STS) interpreting education. The university course in STS and interpreting is three years in duration, leading to a BA in translation studies.

Because there is no prerequisite for the students to know any STS before they begin the program, the first year mostly consists of courses in STS, including both practical training (i.e. language skills courses) and theoretical subjects (i.e. courses in STS grammar and structure, and in Deaf culture and history, etc.). In the second year, similarly practical and theoretical interpreting courses are introduced, while the students still receive STS practical training. Finally, in the third year, no STS practical training is offered, but the focus is instead primarily on interpreting in theory and practice. Figure 1 illustrates how the interpreter program curriculum is designed.

\begin{tabular}{|c|c|c|c|c|c|}
\hline \multicolumn{2}{|c|}{ Year 1} & \multicolumn{2}{|c|}{ Year 2} & \multicolumn{2}{|c|}{ Year 3} \\
\hline Semester 1 & Semester 2 & Semester 3 & Semester 4 & Semester 5 & Semester 6 \\
\hline $\begin{array}{l}\text { SSL } 1 \\
\text { (10 credits) }\end{array}$ & $\begin{array}{l}\text { Perspectives on } \\
\text { language } \\
\text { ( } 5 \text { credits) }\end{array}$ & $\begin{array}{c}\text { SSL } 5 \\
\text { (7,5 credits) }\end{array}$ & $\begin{array}{c}\text { SSL } 6 \\
\text { (7,5 credits) }\end{array}$ & $\begin{array}{l}\text { Tactile SSL } \\
\text { (5 credits) }\end{array}$ & $\begin{array}{l}\text { Degree project } \\
\text { (15 credits) } \\
\text { Student thesis }\end{array}$ \\
\hline $\begin{array}{l}\text { Linguistic } \\
\text { introduction to SSL } \\
(5 \text { credits })\end{array}$ & $\begin{array}{l}\text { SSL } 3 \\
\text { (7,5 credits) }\end{array}$ & $\begin{array}{l}\text { Text Analysis } \\
\text { ( } 7,5 \text { credits) }\end{array}$ & $\begin{array}{l}\text { Professional Ethics } \\
\text { ( } 7,5 \text { credits) }\end{array}$ & $\begin{array}{l}\text { Linguistic variation } \\
\text { (5 credits) }\end{array}$ & \\
\hline $\begin{array}{c}\text { SSL } 2 \text { practical } \\
\text { focus } \\
\text { (7 credits) }\end{array}$ & $\begin{array}{l}\text { Language } \\
\text { structures } \\
\text { ( } 5 \text { credits) }\end{array}$ & $\begin{array}{l}\text { Introduction to } \\
\text { interpreting theory } \\
(7,5 \text { credits })\end{array}$ & $\begin{array}{l}\text { Terminology } \\
\text { (5 credits) }\end{array}$ & $\begin{array}{l}\text { Theory and } \\
\text { methodology } \\
\text { (5 credits) }\end{array}$ & \\
\hline $\begin{array}{l}\text { SSL } 2 \text { theoretical } \\
\text { focus } \\
\text { ( } 3 \text { credits) }\end{array}$ & $\begin{array}{l}\text { Oral language } \\
\text { production } \\
\text { ( } 5 \text { credits) }\end{array}$ & $\begin{array}{c}\text { Interpreting } 1 \\
\text { ( } 7,5 \text { credits })\end{array}$ & $\begin{array}{l}\text { Interpreting } 2 \\
\text { (10 credits) }\end{array}$ & $\begin{array}{l}\text { Applied Practice } \\
\text { (5 credits) }\end{array}$ & $\begin{array}{l}\text { Interpreting } 4 \\
\text { ( } 7,5 \text { credits) }\end{array}$ \\
\hline $\begin{array}{c}\text { Deaf culture and } \\
\text { history } \\
\text { ( } 5 \text { credits })\end{array}$ & $\begin{array}{c}\text { SSL } 4 \\
\text { (7,5 credits) }\end{array}$ & & & $\begin{array}{l}\text { Interpreting } 3 \\
\text { (10 credits) }\end{array}$ & $\begin{array}{c}\text { Interpreting } 5 \\
\text { ( } 7,5 \text { credits })\end{array}$ \\
\hline
\end{tabular}

Figure 1. The Swedish interpreter program curriculum.

\footnotetext{
${ }^{1}$ The Swedish Folk high school is an alternate form of adult education that provides general civic education and the courses may be equated with the upper secondary school. See further https://www.folkhogskola.nu/globalassets/dokument-och-filer/folk-high-school---eligibility-higher-educationand-higher-vocational-education_criteria.pdf
} 
In Figure 1, blue boxes show STS skills training, orange boxes interpreting skills training, green boxes STS related theory courses and yellow boxes theory courses related to spoken language. The purple colour is an internship course and the dark yellow a course focusing on both signed and spoken language from a contrastive perspective. The red box is a graduation course in which the students write their BA thesis. The colours indicate the main focus in the courses although for example in the STS courses 3-6, theoretical elements are also included, and in some more theoretical courses, practical elements are included.

With only two years of STS skills training (a total of approximately 600 hours) the students are expected to learn as much STS as required in order to start the interpreting process. This is obviously a very short time period in which to learn a new language at a level good enough to be able to interpret to and from it. Therefore, the STS teaching per se is also very important. But while there is a growing body of research on sign language second language (L2) acquisition internationally (see e.g. Bel, Ortells \& Morgan, 2015; Ferrara \& Nilsson, 2017; Ortega \& Morgan, 2015), to a large extent, this has not focused on the teaching of an L2 sign language. The university teachers who teach STS have therefore (almost) no scientific knowledge of how they should conduct their instruction in the most effective way. In the Swedish context, the government has decided that STS education will be based on both scientific knowledge and proven experience. By 'proven experience', the Swedish National Agency for Higher Education intends something that is more than just experience:

It is [experience that is] tried and tested. This requires that it has been documented, in each case communicated in such a way as to allow it to be shared with others. It must also have been reviewed in a collegial context, based on criteria that are relevant to the operational content of the specific experience. It should also have been assessed based on ethical principles: not all experience is benign and thus worth following. (Swedish National Agency for Higher Education, 2008, cited in Skolverket, 2014, p. 12).

For STS instruction, there is no process for creating proven experience, and therefore the teachers do not have this proven experience to rely on. According to Quinto-Pozos (2011), the lack of research and publications on pedagogical issues in (American) sign language teaching has led to a situation where sign language teachers have had to rely on their own linguistic intuition and cultural beliefs when they teach hearing L2 learners. This has also been the case in Sweden. However, when the Stockholm university program in STS interpreting started, new opportunities to conduct research on STS L2 learning and instruction appeared and two large projects were started; one with a linguistic focus through the creation of an STS L2 corpus, the project TATE (Schönström \& Mesch, 2017), and one with the focus on teaching STS as L2, the project UTL2 (Holmström, 2018a, 2018b). This article builds on data from the latter project, UTL2, which will be further described below.

In the UTL2 project, one sub-study examined how the students' (practical) STS acquisition should be best facilitated if the instruction from the very beginning was given mainly in STS through STS first language (L1) teachers (with additional use of written Swedish through PowerPoint slides and whiteboard notes) or in spoken Swedish through a STS L2 teacher (who was hearing and talked about STS through the medium of Swedish, but showed signs and used STS texts in her teaching). The results from this sub-study showed no differences in the students' STS signing skills after the first semester, but it appeared that the students who had received their initial instruction from the L2 teacher gained better metalinguistic knowledge of STS. Therefore, although the analysis of L1 and L2 teachers' teaching all revealed interesting features and patterns, this article aims to more closely examine in particular how the L2 teacher instructed the students. More specifically, this study examines the L2 teacher's specific teaching methods, the recurring patterns in her classroom instruction, and how these differ from those of the L1 teachers.

\section{LITERATURE REVIEW}

\section{A. Learning a Language in Another Modality}

Hearing students who only have learnt spoken language(s) before they begin STS classes not only learn a new language (an L2), but they also have to learn to understand and express this language through another modality than in their L1 (see e.g. Chen Pichler \& Koulidobrova, 2015). The students need to learn to use their bodies in expressing the language, not only the hands and arms, but also the head and face. Sign languages also have a different structure than spoken languages. Characteristics of sign languages are, among other things, that they use the space in front of the body to place signs, they can express several linguistic elements simultaneously, and the signs are highly iconic.

Woll (2013) identified seven features of sign language that impact on L2 learning of it: 1) learnability (the difficulty of learning to use the body to express language); 2) iconicity (a large proportion of signs are visually motivated and new strategies to aid the memory for how signs are to be expressed need to be developed); 3) phonology and motor skills (new motor skills have to be acquired, and already developed motor dexterities have to be re-learned in order to express them as language with the correct phonology); 4) the role of the face (facial expressions also need to be reanalysed as linguistic features and used as such); 5) grammar (another grammar, and way to express grammar, than in spoken language needs to be learned); 6) the role of gesture (i.e. the possibility of using pre-existing visual-spatial skills from gesturing as transfers); and 7) social issues (the possibility of interacting with deaf people outside the classroom). Chen Pichler and Koulidobrova (2015), similarly, mention areas for modality effects on hearing L2 learning of a sign language: phonology (the differences between how spoken and signed languages are expressed); space in front of the 
body (which is used in another and more explicit way than in spoken languages); and iconicity. They describe hearing learners who for the first time learn a sign language as M2-L2 learners, where M2 stands for the learning of expressing language in a "second modality".

The modality differences between the expression of spoken versus signed languages have consequences for the L2 learning of STS. Previous research on L2 acquisition for spoken languages cannot just be transferred onto the teaching of sign languages, because the modality differences also have to been taken into account. It is however undoubtedly true that certain L2 phenomena found in spoken language acquisition, such as language transfers and language universals can also be applied to L2 sign language acquisition (Chen Pichler \& Koulidobrova, 2015).

\section{B. Teaching a Language in Another Modality}

In the twentieth century, language teaching was established as a profession and became treated as such. During the following century, many teaching methods were developed and applied, leading to sometimes competing ideologies in language teaching (Richards \& Rodgers, 2001). For example, methods such as the direct method, the audiolingual method and the communicative language teaching approach have been used in different contexts, with their points of departure in different teaching ideologies. However, as mentioned in the introduction, sign languages appear not to have been a significant focus in the research on teaching methods. This perception is confirmed through an overview of studies that have been performed recently in the field of American Sign Language (ASL) teaching by Quinto Pozos (2011). He shows, among other things, that in general there are no studies which have empirically examined the efficacy of the teaching strategies used in adult L2 ASL instruction, nor has the efficacy of one ASL curriculum over another been examined. The teachers have to a large extent been forced to use a trial and error approach, continuously adjusting and improving their lessons and activities. This is also true in the Swedish context. Linguistic research on STS has only been conducted since the 70s and is therefore still quite sparse, and as a consequence, only a very few studies have examined different STS contexts. For example, there are no previous studies which have examined STS L2 instruction, and therefore, teachers have had to use L2 acquisition research on spoken language in a trial and error approach, as highlighted by Quinto Pozos (2011).

\section{The Native versus Non-native Teacher}

Riordan (2018) highlights the differences between native and non-native speaker language teachers when teaching learners of a target language in non-immersion school environments. In these settings, the teacher is often the primary source for the students regarding the target language and its culture, and according to Riordan, native speaker teachers are often preferred by institutions. These teachers have natural and deep knowledge in the language of instruction and can thus become role models for the students in their endeavour to learn the new language in depth. Nevertheless, research has shown no evidence that native speakers are better language teachers for L2 learners than non-native speaker language teachers. It may in some cases instead be the opposite: "Speakers who have learnt a language at a later stage may... have explicit language awareness combined with metalinguistic knowledge. These skills are particularly important for language teachers, who may be required to provide explanations of grammatical forms or usage norms to their students." (Riordan, 2018, p. 148). Riordan suggests that non-native speaker language teachers often have a greater knowledge of such grammatical forms and of usage norms, and that they can explain these at a level that is comprehensible for the students. Native speaker language teachers instead have intuitive knowledge of the language. A native speaker often knows how the language should be expressed correctly, but an L2 language teacher may also be consciously aware of specific aspects of the language that differ from the students' L1, and may be more experienced and aware of it, and thus better able to explain these aspects to students.

Non-native speaker language teachers may have different linguistic deficits, for example regarding vocabulary, fluency and pronunciation, but for the students, they can become role-models for bilingual speakers (Medgyes, 2017; Riordan, 2018). Through their language forms and use, and their pronunciation and grammar, they show the students how a bilingual individual can work and act. The students may see the native speaker language teacher's language proficiency as unattainable, while the non-native speaker language teachers give a more attainable model for usage of the target language. Also, students can learn from this how they can code-switch in a bilingual way and use their bilingual competence in different ways.

In the context of sign language teaching, there is an issue of whether the teachers should be solely deaf (i.e. native speakers of a sign language) $)^{2}$ or whether hearing teachers (i.e. non-native speakers) can also be teachers of sign languages - and if spoken language should be allowed or not in the teaching of the latter. For example, Quinto-Pozos (2011) states that several institutions have decided that no spoken language is allowed in the sign language teaching context, irrespective of the teachers' hearing status. But he also mentions that spoken language does have a role in teaching, for example through (deaf teachers') sporadic use of interpreters, and through hearing teachers' use of speech in shorter sequences to explain things when a learner has not understood the content or signing. This issue is however not trivial, because there is globally a long history of hearing people's oppression of deaf people and their sign languages. Therefore, it is important to mention that in all sign language instruction, deaf teachers are very important because they have fluency in their signing and deep knowledge of the language. They also have the experience of being

\footnotetext{
${ }^{2}$ Native speakers of sign languages can however also be hearing children of deaf parents.
} 
visual language users and know what it means to be deaf in a hearing world. This is not to say that hearing teachers cannot teach a sign language too, in close cooperation with deaf teachers, aiming to teach from just the M2-L2 perspective. In Riordan's (2018) description of the non-native speaker language teachers' teaching, for example they use both their common language and the target language in the classroom, just as bilinguals do, often with the aim of explaining things on a metalinguistic level that may differ particularly in the target language through the use of the language they have in common.

\section{METHODOLOGY}

\section{A. The Project UTL2}

To address the lack of scientific knowledge and proven experience in the context of STS instruction, the project UTL2 (Teaching Swedish Sign Language as a second language to interpreter students) was started in 2016 with the aim of enhancing teachers' knowledge about effective ways of teaching STS as an L2. A further aim was to examine how teaching can lead to students making good progress and attaining a deep knowledge in STS (see e.g. Holmström, 2018a). The project uses action research as its main method. The project is grounded in a desire to change, develop and improve the teachers' own practice, and to gain new knowledge about issues that are experienced as problematic. With action research, connections can be made between theory and practice, as well as between reflections and actions (see, e.g., McAteer, 2013). Action research promotes the needs and values that exist in teaching practice and provides opportunities to examine teaching practice from the inside, in a close cooperation between teachers and researchers.

Until now, two sub-studies have been completed as a part of UTL2, and a third is ongoing. In this article, data are used from the first of these sub-studies, Initial teaching through different primary languages. This sub-study aims to explore the best possible way to begin teaching, for the purposes of L2 students learning a language in a new modality. This could be through initial instruction in spoken Swedish by hearing L2 teachers, or directly in STS by deaf L1 teachers. The study examines this issue through the testing of two different teaching methods during the first three weeks of STS instruction. The students, who had no previous knowledge of STS (except for knowing the hand alphabet and/or a few single signs), were randomly divided into two groups, A and B, consisting of 12 and 13 students respectively (the median age in group A was 24.5 years and group B 24 years. Only one of the students was a man). In group A, the teaching was primarily conducted by deaf teachers in STS, while the medium of instruction in group B primary was spoken Swedish, as used by hearing teachers. After the first three weeks, this was changed, so that all of the students were instructed through both STS and spoken Swedish (in different lessons), although most of the teaching was conducted in STS by deaf teachers.

\section{B. STS Tests and Students' Course Grades}

Two tests were used in order to examine whether any differences appeared between the two groups, both initially and in the longer term. One test was an elicited imitation task, SignRepL2, developed for the purpose of testing STS L2 global language fluency. In the test, the students watch video clips with sentences produced by a native signer and thereafter they imitate as exactly as possible the sentence they just have viewed (see Holmström, 2018a; Schönström \& Holmström, 2017). For a deeper description of such sentence reproduction tests, see Hauser, Paludneviciene, Supalla \& Bavelier, (2008).

The other test developed was a phonological test in which the students watch video clips with different one- and twohanded signs. After each clip, they try to identify the signs' hand shape, location and movement with the help of different pictures on a sheet of paper (see further Balkstam, 2018; Holmström, 2018a).

These two different tests were first conducted before the students started the course, and were thereafter repeated three times: after half a semester when the first STS practical training course was finished (i.e. after 100 hours, approximately 8 weeks of instruction), after one semester when the second STS practical training course was completed (after 200 hours), and after one year when the third and fourth STS practical training courses ended (after 400 hours). The results from the tests however did not uncover differences between the groups, except from the second SignRepL2 session. In this, group A showed some better fluency than group B. This was also expected because group A had received most instruction through STS until then, while group B had received much more instruction through spoken Swedish during the first three (of eight) weeks. But the difference between the groups had disappeared in the following test occasions.

In order to find out if there were other differences, the students' course grades from all the five courses in the first semester (see Figure 1) were also compared on the group level. Almost no differences between the groups from the first semester's two STS practical signing skills courses (the first one graduated after 100 hours of instruction, and the other one after 200 hours) could be detected. But, in the three theoretical courses given during the first semester, it appeared that group B received higher grades than group A, indicating that their theoretical understanding of STS was better developed. This was the greatest difference revealed between the groups, and a control was made of the students' previous educational background, grades from upper secondary school, experience from learning other languages, and whether the student had Swedish as second language. This control showed that the groups had very similar backgrounds and thus there were no background factors influencing the results. It is also important to mention that in the theoretical course Linguistic introduction to STS, the teacher of both groups was the same hearing STS L2 teacher who also taught 
group B in the practical course the first three weeks in the sub-study. In the other two theoretical courses; Deaf culture and history, and STS 2 theoretical focus, the teachers of both groups were deaf (not the same teachers as in the practical courses) and taught with the help of STS interpreters.

\section{The Present Study}

The instruction in the two groups during the first three weeks was also captured through video recordings of four lessons (1,5 hour each) per week for each group (in total 18 hours of video documentation), and it is these recordings that this article focuses on. Two cameras were used in each lesson, one directed towards the teacher and one towards the students. Because the focus in the analysis here was primarily the teacher's instruction, it is the recordings from the camera directed towards the teacher that primarily have been used in this study. It was supposed that group B's greater knowledge of STS theory may originate in the initial instruction through spoken Swedish by the STS L2 teacher, and therefore, it was of particular interest to examine just this teacher's instruction more closely in order to identify recurring patterns and particular characteristics in her teaching. This STS L2 teacher is a non-native speaker language teacher, who has a background as STS interpreter. She began to learn STS in her twenties and was in her late fifties when the study was conducted. She worked as an STS interpreter for many years, and still does so sporadically in her spare time. She has studied STS linguistics up to BA level but has not received her BA degree. She has worked as a teacher in STS since the early 2000s and is very engaged in pedagogical issues together with the other teachers in the university team, who are all deaf.

All the recordings from the STS L2 teacher's lessons have been examined, and recurring patterns that appeared in them have been noted. Thereafter, illustrative examples from these patterns were chosen and analysed with the help of the annotation tool ELAN (EUDICO Linguistic Annotator), a flexible computer-based tool for analysing (sign) language texts through linking video sequences and transcriptions. In the analysis, different tiers in this software were used for annotating the teacher's use of the different languages (i.e. spoken Swedish and STS), and another tier for her use of gestures. One tier was also used for comments.

\section{RESUlts AND ANALYSIS}

In this section, three illustrative examples from the teaching will be used in order to describe the STS L2 teacher's instruction with respect to certain features in the students' M2-L2 learning: i) the different view of hand shape orientations; ii) constructed action; and iii) iconicity. The extracts are displayed in blocks in tables, where the first row consists of the Swedish spoken by the teacher. The second row, in italics, is an English translation of the spoken Swedish, and the third one is signs from STS transcribed in capital letters. ${ }^{3}$ The fourth and last row consists of descriptions, comments and explanations of the situation or the teacher's behaviour, between brackets. The STS signs and the comments are placed to show where in the utterances they are used in relation to the spoken Swedish. In the text below, shorter extracts are provided. Extended extracts can be found in Appendix A-C.

\section{A. The Different View of Hand Shape Orientations}

The L2 teacher appear as well aware of STS being in another modality, in the classroom instruction. Among other things, she explicitly explains the different view of signs for a signer and an addressee. Because signs are produced with the signer's own hands, their point of view is from their own eyes while the addressee perceive the signer's hand shapes from the opposite point of view. For example, if the signer produces a sign in the form of a thumbs-up, he or she looks at the palm side of the hand, while the addressee instead looks at the back of the hand (Figure $2 \mathrm{a}, \mathrm{b}$ ).

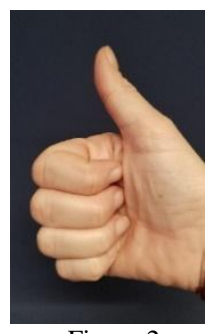

Figure 2a

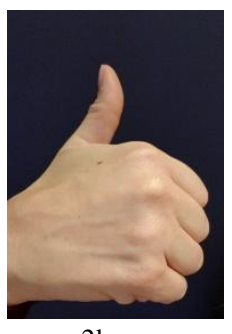

$2 \mathrm{~b}$

Excerpt 1 illustrates how the STS L2 teacher makes the students aware of this phenomenon through explicitly talking about the different views, and how the signs looks different depending on whether the students are reading or producing the sign. She starts by using a web page, visible on the screen, with an illustration of a drawn hand shape, together with a film clip where an actor produces the same hand shape. She points at the screen, asking the students what the difference is between the illustration and the film. Thereafter, she points out that the hand shape is viewed from

\footnotetext{
${ }^{3}$ In the literature, it is a general convention to use capital letters for representing signs in written text. In the transcripts, sometimes there is a hyphen between two words, indicating that several words are needed for expressing the meaning of the sign. In addition, on one occasion '@rd' is added after the word WALK, adding a meaning of "long-time walking". This reflects sign movement being reduplicated several times.
} 
different angles in both of them, and holds up her own hands and rotates them in the different directions in order to make the angle differences explicit for the students. Thereafter, she went on to talk about the sign LIVE:

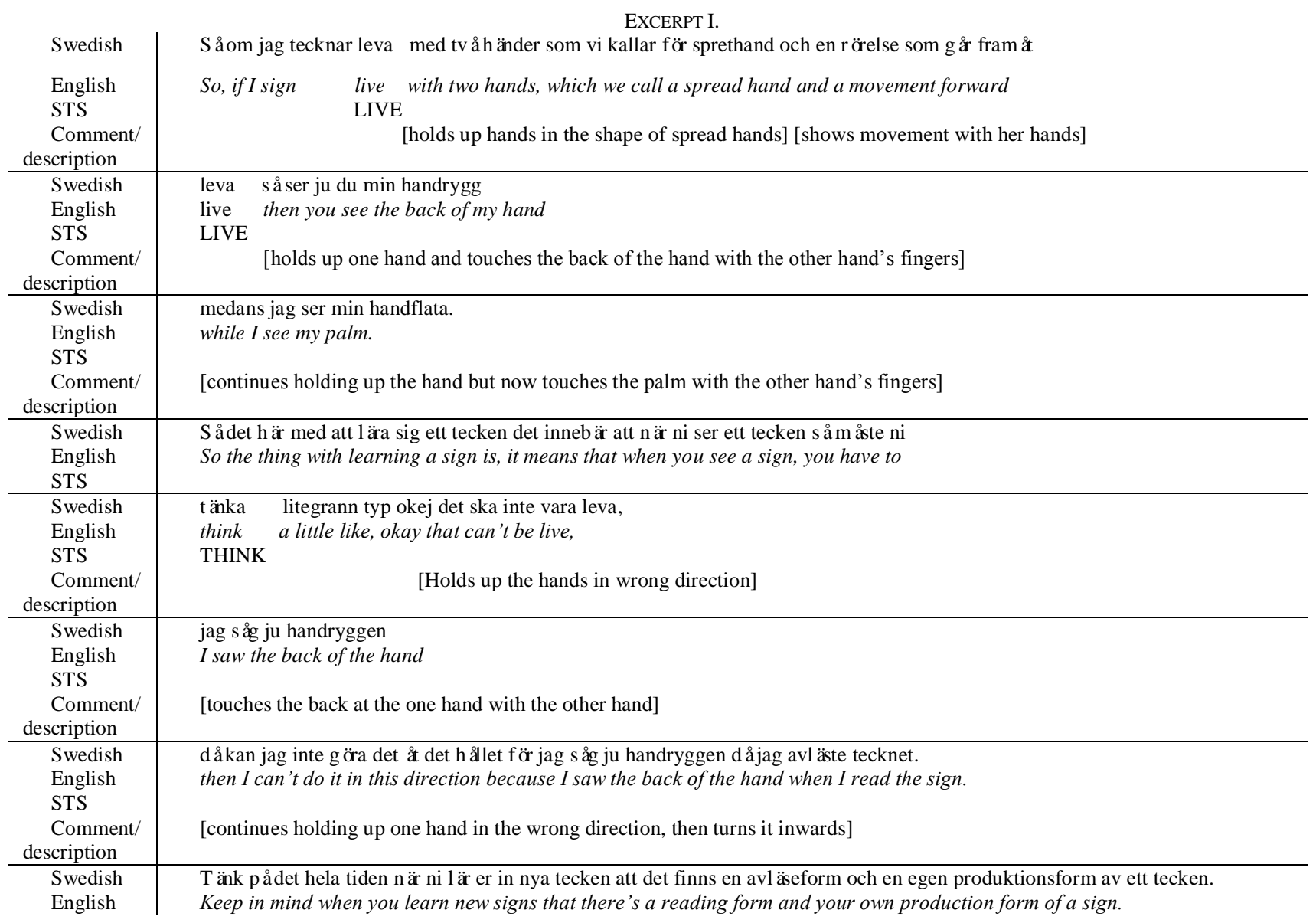

The teacher here signs LIVE in its correct orientation, and thereafter in the opposite orientation while she talks about the phenomena of different views of the hand shape orientations. During the lesson, the teacher frequently holds up her hand(s) and explains what the students are looking at, such as the palm or the back of the hand, and sometimes she shows the STS signs as just signs. The teacher here mentions that the students have to learn to understand both views of all signs in order to learn both to correctly produce signs themselves, and to understand what a signer produces.

\section{B. Constructed Action}

In sign languages, a common way to represent a referent's actions, utterances, feelings, thoughts etc. (both actual and imagined) is to use constructed action (Metzger, 1995). This means that the signer uses the hands, head, face and body in order to, for example, retell a dialogue or show how an action was carried out. Students who learn an L2 sign language need to learn how such constructed action is performed and how they can understand the narratives they are told. In excerpt 2, the teacher plays a film on the screen. She shows short sequences and repeatedly stops the film, asking the students what they saw the actor perform. The students give suggestions, and the teacher extends and deepens these, pointing out particular features in the narration. In particular, she mentions the common features that are specific for sign languages, for example as in this extract, the actor's use of constructed action in a story about a dog. 
EXCERPT II.

\begin{tabular}{|c|c|}
\hline $\begin{array}{l}\text { Swedish } \\
\text { English } \\
\text { STS } \\
\text { Comment/ } \\
\text { description }\end{array}$ & $\begin{array}{l}\text { Gå ja. Det här är ett fast tecken för gå, men ni ser att han gör något också, med kroppen } \\
\text { Walk yes. This is a lexical sign for walking, but you see that he also does something with his body } \\
\text { WALK@rd-- }\end{array}$ \\
\hline $\begin{array}{l}\text { Swedish } \\
\text { English } \\
\text { STS } \\
\text { Comment/ } \\
\text { description }\end{array}$ & $\begin{array}{l}\text { Vi har ju inte pratat så mycket om vad resten av kroppen gör } \\
\text { We haven 't talked so much about what the rest of the body does } \\
\text { [continues]------- } \\
\qquad \text { [continues to move only her body]---------- }\end{array}$ \\
\hline $\begin{array}{l}\text { Swedish } \\
\text { English } \\
\text { STS } \\
\text { Comment/ } \\
\text { description }\end{array}$ & $\begin{array}{l}\text { vi har ju bara pratat om tecknen. } \\
\text { we've just talked about the signs. } \\
\text { SIGN--------------------- } \\
\text { [repeating the sign movement while talking] }\end{array}$ \\
\hline $\begin{array}{l}\text { Swedish } \\
\text { English } \\
\text { STS } \\
\text { Comment/ } \\
\text { description }\end{array}$ & $\begin{array}{l}\text { Nu ska vi börja titta på vad gör resten av kroppen och framförallt, vad gör han med ansiktet. } \\
\text { Now let's start looking at what the rest of the body does and above all, what he does with his face. } \\
\qquad \text { [hands on shoulders and moves her body ][creates a circle in front of her face] }\end{array}$ \\
\hline $\begin{array}{l}\text { Swedish } \\
\text { English } \\
\text { STS } \\
\text { Comment/ } \\
\text { description }\end{array}$ & $\begin{array}{ll}\text { Vad, alltså vad är det här? } & \text { Det är en glad hund, } \\
\text { What, so what was this? } & \text { It's a happy dog, } \\
& \\
\text { [shows a film clip in STS] } & \end{array}$ \\
\hline $\begin{array}{l}\text { Swedish } \\
\text { English }\end{array}$ & $\begin{array}{l}\text { och nu har vi för första gången sett en man i grön tröja bli en glad hund. } \\
\text { and now for the first time we've seen a man in a green sweater become a happy dog. }\end{array}$ \\
\hline $\begin{array}{l}\text { Swedish } \\
\text { English }\end{array}$ & $\begin{array}{l}\text { För det som händer nu i våra huvuden är att vi omedelbart accepterar att han gestaltar en hund. } \\
\text { Because what happens now in our minds is that we immediately accept that he represents a dog. }\end{array}$ \\
\hline $\begin{array}{l}\text { Swedish } \\
\text { English }\end{array}$ & $\begin{array}{l}\text { Han säger inte om hunden, han blir hunden. } \\
\text { He doesn't talk about the dog, he becomes the dog. }\end{array}$ \\
\hline
\end{tabular}

Here, the STS L2 teacher starts by mentioning how the actor uses his body in the narrative, and highlights the fact that the class has not focused much on body movements in signing before, and it is now time to learn more about them. She says that the class will focus in particular on what the actor does with his face, and asks the students what they perceive from it. Thereafter, she concludes that we perceive the narration as a happy dog, despite the fact that in reality it is a man in a green sweater that is signing. She mentions that in our mind, as addressees, we accept that the actor, through his use of body movements and facial expressions, takes the role of the dog he is talking about, and thus "becomes the dog." She also mentions that this is a common feature in STS, and that it differs from how narratives are expressed in spoken languages. This excerpt thus illustrates how the students, through looking at and discussing different STS narratives, learn how stories etc. are told in STS and how the students will perceive them in different ways. The students also are made aware of the nuances in body movements and facial expressions, and that they must not only consider what the hands are doing when they read sign language. This also supports their own sign production through their growing awareness of the importance of using the whole body in their signing.

\section{Iconicity}

Iconicity can be defined as a resemblance between form and meaning. That is, it is possible to figure out the meaning of an iconic sign because it looks like what it means (Taub, 2012). For example, when performing the STS sign DRIVE, the signer holds up her/his hand as if holding a steering wheel when driving, and moves the sign forward. Iconicity does exist in both sign and spoken languages, but is more pervasive in sign languages "because the resources of sign languages lend themselves to presenting visual, spatial, and motor images, whereas the resources of spoken languages only lend themselves to presenting auditory images." (Taub, 2012, p. 408). In the STS L2 instruction, it is important to make the students aware of the iconicity in the language, and the student learns about it in both theory and practice. As shown in excerpt 3 , the teacher uses a narrative film about different animals that crawl into a glove, and discusses the actor's choice of different hand shapes depending on which animal he illustrates. 


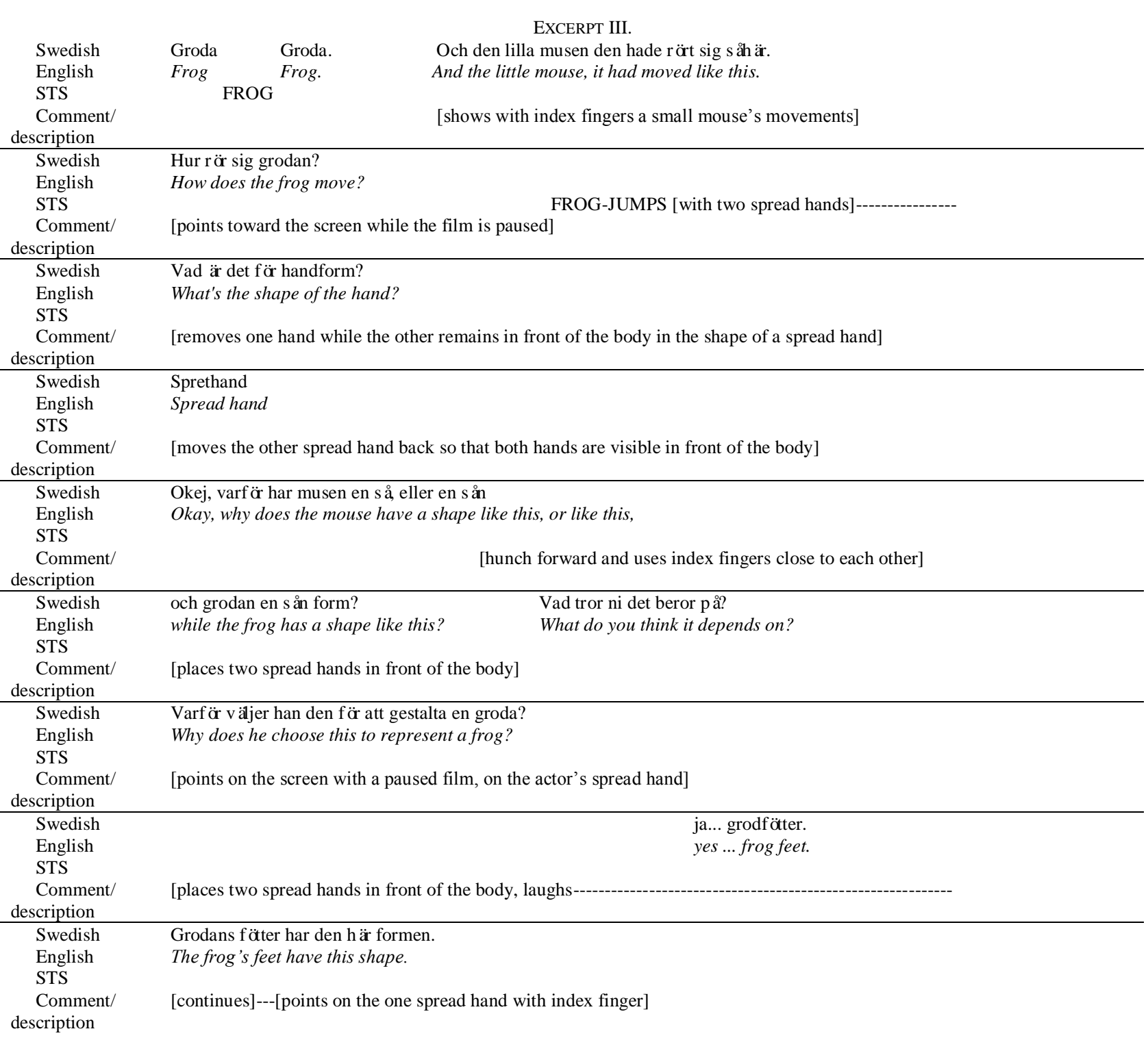

In this excerpt, the teacher discusses differences in how the narrative is expressed, depending on if it is a mouse or a frog that is in focus. She shows with her index fingers how the mouse moves, indicating that it is a small animal, and compares this signing with the use of both hands in spread hand shapes when the narrative is about the frog. In similar ways, she shows the movement patterns that differ between the mouse and the frog, and discusses with the students why the different hand shapes and movements are used. But it also appears in this part of the lesson that the teacher adds theoretical knowledge to the discussion, through introducing the concept of iconicity, and what it means in STS (see Appendix C). She tells the students that the way to choose hand shapes is an issue of iconicity, and asks the students if they know what this concept means. The class discuss the meaning and the teacher concludes that it is something similar to a picture that can be done by the hands, and that it is not possible in spoken languages, but is a particular feature of sign languages. The students thereby both learn how narratives are expressed with different hand shapes and movement, depending on what the narrative is about, and they receive metalinguistic knowledge of what this production means from a theoretical perspective.

\section{DisCUSSION AND CONCLUSIONS}

In this article, the STS L2 teacher's different teaching approaches have been examined and three recurring patterns have been analysed in depth. These patterns have revealed that the STS L2 teacher provides, to a high degree, metalinguistic knowledge for the students in her teaching through both show signs and narratives and talk about the features that appear in them. Just as Riordan (2018) highlights about the non-native language teacher, the STS L2 teacher appears very aware of STS linguistic structure, and she explains different features that are specific for STS in her teaching. She also frequently compares STS and Swedish. She does not appear as a bilingual role model in the way that Medgyes (2017) and Riordan (2018) suggest, but her experiences from being an L2 learner seem to be of great importance. She often makes explanations about both linguistic features she herself has struggled with, and things she 
knows that many hearing students have difficulties with, particularly those that are modality specific.

The analysis of the STS L1 teachers' instruction (which has not been the focus in this article) revealed that the students by them got extended training in becoming more visually oriented in their communication. They were trained to make and keep eye contact, how to get attention, how to use visual turn-taking, etc. In addition, they also were trained to use different strategies in order to communicate with deaf people: through signs, fingerspelling, gestures and written notices. The deaf teachers helped each student to perform signs, they went through different lists of signs, with the teacher showing how to produce them, and the teacher gave many examples of signs and expressions. One thing that was discovered through this analysis of the STS L1 teachers' instruction was that the benefits from this teaching were not mentioned in the requirements in the course goals, nor were they caught in the STS tests. It may be because of this lack that no differences were found between the two groups that received different initial instruction regarding practical signing.

Although the students themselves in interviews express appreciation for having deaf teachers as these are perceived as role models for how STS should be expressed, and because they are forced to use STS when communicating with them, the STS L2 teacher is also very much appreciated by the students, because they can ask questions and get deep and extended explanations from her. This result, together with the other results from this action research project has pedagogical implications: it appear that is important to allow for the use of spoken language in STS instruction, and to give both languages their natural place. Sometimes the focus needs to be on building metalinguistic knowledge through spoken Swedish, and sometimes the focus has to be to train to become visually oriented, and produce, read and communicate in STS.

Action research makes it possible to take as the point of departure issues in the practice that teachers may experience as problematic or difficult. In the education context that this study has focused on, one frequently-discussed issue has been whether it is better to start with instruction directly in STS without use of any spoken Swedish, or vice versa. The use of action research has made it possible to test this issue through systematic examination and documentation, with colloquial reflections. The results revealed the importance of having both L1 and L2 STS teachers because these contribute different values in the instruction, all of which are needed for aspiring STS interpreters. Through the study, the teachers could also learn from each other. For example, the L1 teachers could learn from the specific L2 perspective in the L2 teacher's teaching, as shown in this article, and it made them more aware of modality specific difficulties for the students. Thus, the study has led to a change in how the teaching is envisaged and planned, and the teachers' practice has been developed and improved.

\section{APPENDIX A. EXCERPT 1}

\begin{tabular}{|c|c|}
\hline $\begin{array}{l}\text { Swedish } \\
\text { English } \\
\text { SSL } \\
\text { Comment/ } \\
\text { description }\end{array}$ & $\begin{array}{l}\text { Är det någon som på rak arm kan säga mig vad det är för skillnad mellan den som vi nyss såg och den här? } \\
\text { Is there anyone who can tell me off of the top of their head what the difference is between the one we just saw and this one? } \\
\text { [walks to the screen and points at a paused film] }\end{array}$ \\
\hline $\begin{array}{l}\text { Swedish } \\
\text { English } \\
\text { SSL } \\
\text { Comment/ } \\
\text { description }\end{array}$ & $\begin{array}{l}\text { Den var lite omvänd, vad beror det på? } \\
\text { It was a bit reversed, what's the reason for that? }\end{array}$ \\
\hline $\begin{array}{l}\text { Swedish } \\
\text { English } \\
\text { SSL } \\
\text { Comment/ } \\
\text { description } \\
\end{array}$ & $\begin{array}{l}\text { Den första bilden, den som är ritad, den är hur ni ser handen när ni utför tecknet. } \\
\text { The first image, this one that's drawn, it's how you see your hand when you perform the sign. }\end{array}$ \\
\hline $\begin{array}{l}\text { Swedish } \\
\text { English } \\
\text { SSL } \\
\text { Comment/ } \\
\text { description }\end{array}$ & $\begin{array}{l}\text { Det här är, eftersom den är filmad hur tecknet ser ut då ni avläser. } \\
\text { This one is, because it's filmed the way the sign looks when you read it. } \\
\text { [points at the paused film on the screen] }\end{array}$ \\
\hline $\begin{array}{l}\text { Swedish } \\
\text { English } \\
\text { SSL } \\
\text { Comment/ } \\
\text { description } \\
\end{array}$ & $\begin{array}{l}\text { Och det här är en sanning för alla tecken. } \\
\text { And this is true for all signs. }\end{array}$ \\
\hline $\begin{array}{l}\text { Swedish } \\
\text { English } \\
\text { SSL } \\
\text { Comment/ } \\
\text { description } \\
\end{array}$ & $\begin{array}{ll}\text { Så om jag tecknar } & \text { leva } \\
\text { So, if I sign } & \text { live } \\
& \text { LIVE }\end{array}$ \\
\hline $\begin{array}{l}\text { Swedish } \\
\text { English } \\
\text { SSL } \\
\text { Comment/ }\end{array}$ & $\begin{array}{l}\text { med två händer som vi kallar för sprethand } \\
\text { with two hands, which we call a spread hand } \\
\text { [holds up both hands in the shape of spread hands] }\end{array}$ \\
\hline
\end{tabular}




\begin{tabular}{|c|c|}
\hline $\begin{array}{l}\text { Swedish } \\
\text { English } \\
\text { SSL } \\
\text { Comment/ } \\
\text { description }\end{array}$ & $\begin{array}{l}\text { och en rörelse som går framåt } \\
\text { and a movement forward } \\
\text { [shows the movement with her hands] }\end{array}$ \\
\hline $\begin{array}{l}\text { Swedish } \\
\text { English } \\
\text { SSL } \\
\text { Comment/ } \\
\text { description }\end{array}$ & $\begin{array}{l}\text { leva } \\
\text { live } \\
\text { LIVE }\end{array}$ \\
\hline $\begin{array}{l}\text { Swedish } \\
\text { English } \\
\text { SSL } \\
\text { Comment/ } \\
\text { description } \\
\end{array}$ & $\begin{array}{l}\text { så ser ju du min handrygg } \\
\text { then you see the back of my hand } \\
\text { [holds up one hand and touches the back of the hand with the other hand's fingers] }\end{array}$ \\
\hline $\begin{array}{l}\text { Swedish } \\
\text { English } \\
\text { SSL } \\
\text { Comment/ } \\
\text { description } \\
\end{array}$ & $\begin{array}{l}\text { medans jag ser min handflata. } \\
\text { while I see my palm. } \\
\text { [continues holding up the hand but now touches the palm with the other hand's fingers] }\end{array}$ \\
\hline $\begin{array}{l}\text { Swedish } \\
\text { English } \\
\text { SSL } \\
\text { Comment/ } \\
\text { description }\end{array}$ & $\begin{array}{l}\text { Så det här med att lära sig ett tecken det innebär att när ni ser ett tecken så måste ni } \\
\text { So the thing with learning a sign is, it means that when you see a sign, you have to }\end{array}$ \\
\hline $\begin{array}{l}\text { Swedish } \\
\text { English } \\
\text { SSL } \\
\text { Comment/ } \\
\text { description }\end{array}$ & $\begin{array}{l}\text { tänka litegrann typ okej det ska inte vara leva, } \\
\text { think a little like, okay that can't be live, } \\
\text { THINK } \\
\text { [Holds up the hands in wrong direction] }\end{array}$ \\
\hline $\begin{array}{c}\text { Swedish } \\
\text { English } \\
\text { SSL } \\
\text { Comment/ } \\
\text { description } \\
\end{array}$ & $\begin{array}{l}\text { jag såg ju handryggen } \\
\text { I saw the back of the hand } \\
\text { [touches the back at the one hand with the other hand] }\end{array}$ \\
\hline $\begin{array}{l}\text { Swedish } \\
\text { English } \\
\text { SSL } \\
\text { Comment/ } \\
\text { description } \\
\end{array}$ & $\begin{array}{l}\text { då kan jag inte göra det åt det hållet för jag såg ju handryggen då jag avläste tecknet. } \\
\text { then I can't do it in this direction because I saw the back of the hand when I read the sign. } \\
\text { [continues holding up one hand in the wrong direction, then turns it inwards] }\end{array}$ \\
\hline $\begin{array}{l}\text { Swedish } \\
\text { English } \\
\text { SSL } \\
\text { Comment/ } \\
\text { description } \\
\end{array}$ & $\begin{array}{l}\text { Tänk på det hela tiden när ni lär er in nya tecken att det finns en avläseform och en egen produktionsform av ett tecken. } \\
\text { Keep in mind when you learn new signs that there's a reading form and your own production form of a sign. }\end{array}$ \\
\hline $\begin{array}{l}\text { Swedish } \\
\text { English } \\
\text { SSL } \\
\text { Comment/ } \\
\text { description } \\
\end{array}$ & $\begin{array}{l}\text { Så när ni lär er tecken från lexikon, det ni ser är det den andra personens ska se då ni utför tecknet. } \\
\text { So when you learn a sign from the dictionary, what you see is what the other person should see when you perform the sign. }\end{array}$ \\
\hline $\begin{array}{l}\text { Swedish } \\
\text { English } \\
\text { SSL } \\
\text { Comment/ } \\
\text { description } \\
\end{array}$ & $\begin{array}{l}\text { Det kanske låter som att slå in öppna dörrar men ni kommer att upptäcka att ibland } \\
\text { It may sound like pushing against an open door, but you will find that sometimes }\end{array}$ \\
\hline $\begin{array}{l}\text { Swedish } \\
\text { English } \\
\text { SSL } \\
\text { Comment/ } \\
\text { description } \\
\end{array}$ & $\begin{array}{ll}\text { utför man tecknet spegelvänt eftersom man inte } & \text { tänker på att det finns två former. } \\
\text { the sign is mirrored because you don 't } & \text { consider that there are two shapes. } \\
& \text { THINK }\end{array}$ \\
\hline
\end{tabular}

APPENDIX B. EXCERPT 2

\begin{tabular}{|l|l|}
\hline Swedish & Gå ja. \\
English & Walk yes. \\
SSL & WALK@rd----- \\
Comment/ & \\
description & \\
\hline
\end{tabular}




\begin{tabular}{|c|c|}
\hline $\begin{array}{l}\text { Swedish } \\
\text { English } \\
\text { SSL } \\
\text { Comment/ } \\
\text { description }\end{array}$ & $\begin{array}{l}\text { Det här är ett fast tecken för gå, men ni ser att han gör något också, med kroppen. } \\
\text { This is a citation form sign for walking, but you see that he also does something with his body. } \\
\text { [continues]---- }\end{array}$ \\
\hline $\begin{array}{l}\text { Swedish } \\
\text { English } \\
\text { SSL } \\
\text { Comment/ } \\
\text { description }\end{array}$ & $\begin{array}{l}\text { Vi har ju inte pratat så mycket om vad resten av kroppen gör } \\
\text { We haven't talked so much about what the rest of the body does } \\
\text { [continues]---------- [continues to move only her body]----------- }\end{array}$ \\
\hline $\begin{array}{l}\text { Swedish } \\
\text { English } \\
\text { SSL } \\
\text { Comment/ } \\
\text { description }\end{array}$ & $\begin{array}{l}\text { vi har ju bara pratat om tecknen. } \\
\text { we've just talked about the signs. } \\
\text { SIGN------------ } \\
\text { [repeating the sign movement while talking] }\end{array}$ \\
\hline $\begin{array}{l}\text { Swedish } \\
\text { English } \\
\text { SSL } \\
\text { Comment/ } \\
\text { description }\end{array}$ & $\begin{array}{l}\text { Nu ska vi börja titta på vad gör resten av kroppen och framförallt, } \\
\text { Now let's start looking at what the rest of the body does and above all, } \\
\text { [hands on shoulders and moves her body ] }\end{array}$ \\
\hline $\begin{array}{l}\text { Swedish } \\
\text { English } \\
\text { SSL } \\
\text { Comment/ } \\
\text { description }\end{array}$ & $\begin{array}{l}\text { vad gör han med ansiktet. } \\
\text { what he does with his face. } \\
\text { [creates a circle in front of her face] }\end{array}$ \\
\hline $\begin{array}{l}\text { Swedish } \\
\text { English } \\
\text { SSL } \\
\text { Comment/ } \\
\text { description }\end{array}$ & $\begin{array}{l}\text { Vad, alltså vad är det här? } \\
\text { What, so what was this? }\end{array}$ \\
\hline $\begin{array}{l}\text { Swedish } \\
\text { English } \\
\text { SSL } \\
\text { Comment/ } \\
\text { description } \\
\end{array}$ & $\begin{array}{l}\text { Det är en glad hund, } \\
\text { It's a happy dog, }\end{array}$ \\
\hline $\begin{array}{l}\text { Swedish } \\
\text { English } \\
\text { SSL } \\
\text { Comment/ } \\
\text { description }\end{array}$ & $\begin{array}{l}\text { och nu har vi för första gången sett en man i grön tröja bli en glad hund. } \\
\text { and now for the first time we've seen a man in a green sweater become a happy dog. }\end{array}$ \\
\hline $\begin{array}{l}\text { Swedish } \\
\text { English } \\
\text { SSL } \\
\text { Comment/ } \\
\text { description }\end{array}$ & $\begin{array}{l}\text { För det som händer nu i våra huvuden är att vi omedelbart accepterar att han gestaltar en hund. } \\
\text { Because what happens now in our minds is that we immediately accept that he represents a dog. }\end{array}$ \\
\hline $\begin{array}{l}\text { Swedish } \\
\text { English } \\
\text { SSL } \\
\text { Comment/ } \\
\text { description }\end{array}$ & $\begin{array}{l}\text { Han säger inte om hunden, han blir hunden. } \\
\text { He doesn't talk about the dog, he becomes the dog. }\end{array}$ \\
\hline $\begin{array}{l}\text { Swedish } \\
\text { English } \\
\text { SSL } \\
\text { Comment/ } \\
\text { description }\end{array}$ & $\begin{array}{l}\text { Det är jättestor skillnad på hur vi vanligtvis talar när vi talar talspråk, } \\
\text { That's a big difference from how we usually speak when we speak spoken language, }\end{array}$ \\
\hline $\begin{array}{l}\text { Swedish } \\
\text { English } \\
\text { SSL } \\
\text { Comment/ } \\
\text { description }\end{array}$ & $\begin{array}{l}\text { på svenska engelska eller oavsett, så pratar vi inte riktigt såhär... } \\
\text { in Swedish, English or whatever, we don't really speak like this ... }\end{array}$ \\
\hline $\begin{array}{l}\text { Swedish } \\
\text { English } \\
\text { SSL } \\
\text { Comment/ } \\
\text { description } \\
\end{array}$ & $\begin{array}{l}\text { I direkt anförande, som om vi var någon annan eller en annan varelse. } \\
\text { In direct speech, as if we were someone else or another creature. }\end{array}$ \\
\hline $\begin{array}{l}\text { Swedish } \\
\text { English } \\
\text { SSL } \\
\text { Comment/ } \\
\text { description }\end{array}$ & $\begin{array}{l}\text { Det här är väldigt typiskt för teckenspråk } \\
\text { This is very typical for sign language. }\end{array}$ \\
\hline
\end{tabular}


APPENDIX C. EXCERPT 3

\begin{tabular}{|c|c|}
\hline $\begin{array}{l}\text { Swedish } \\
\text { English } \\
\text { SSL } \\
\text { Comment/ } \\
\text { description }\end{array}$ & $\begin{array}{lll}\text { Groda } & \text { Groda. } \\
\text { Frog } & & \text { Frog. } \\
& \text { FROG } & \end{array}$ \\
\hline $\begin{array}{l}\text { Swedish } \\
\text { English } \\
\text { SSL } \\
\text { Comment/ } \\
\text { description }\end{array}$ & $\begin{array}{l}\text { Och den lilla musen den hade rört sig såhär. } \\
\text { And the little mouse, it had moved like this. } \\
\text { [shows with index fingers a small mouse's movements] }\end{array}$ \\
\hline $\begin{array}{l}\text { Swedish } \\
\text { English } \\
\text { SSL } \\
\text { Comment/ } \\
\text { description }\end{array}$ & $\begin{array}{l}\text { Hur rör sig grodan? } \\
\text { How does the frog move? } \\
\text { [points toward the screen while the film is paused] }\end{array}$ \\
\hline $\begin{array}{l}\text { Swedish } \\
\text { English } \\
\text { SSL } \\
\text { Comment/ } \\
\text { description }\end{array}$ & FROG-JUMPS [with two spread hands]------------------ \\
\hline $\begin{array}{l}\text { Swedish } \\
\text { English } \\
\text { SSL } \\
\text { Comment/ } \\
\text { description }\end{array}$ & $\begin{array}{l}\text { Vad är det för handform? } \\
\text { What's the shape of the hand? } \\
\text { [removes one hand while the other remains in front of the body in the shape of a spread hand] }\end{array}$ \\
\hline $\begin{array}{l}\text { Swedish } \\
\text { English } \\
\text { SSL } \\
\text { Comment/ } \\
\text { description }\end{array}$ & $\begin{array}{l}\text { Sprethand } \\
\text { Spread hand } \\
\text { [moves the other spread hand back so that both hands are visible in front of the body] }\end{array}$ \\
\hline $\begin{array}{l}\text { Swedish } \\
\text { English } \\
\text { SSL } \\
\text { Comment/ } \\
\text { description }\end{array}$ & $\begin{array}{l}\text { Okej, varför har musen en så, eller en sån } \\
\text { Okay, why does the mouse have a shape like this, or like this, } \\
\qquad \text { [hunch forward and uses index fingers close to each other] }\end{array}$ \\
\hline $\begin{array}{l}\text { Swedish } \\
\text { English } \\
\text { SSL } \\
\text { Comment/ } \\
\text { description }\end{array}$ & $\begin{array}{l}\text { och grodan en sån form? } \\
\text { while the frog has a shape like this? } \\
\text { [places two spread hands in front of the body] }\end{array}$ \\
\hline $\begin{array}{l}\text { Swedish } \\
\text { English } \\
\text { SSL } \\
\text { Comment/ } \\
\text { description }\end{array}$ & $\begin{array}{l}\text { Vad tror ni det beror på? } \\
\text { What do you think it depends on? }\end{array}$ \\
\hline $\begin{array}{l}\text { Swedish } \\
\text { English } \\
\text { SSL } \\
\text { Comment/ } \\
\text { description }\end{array}$ & $\begin{array}{l}\text { Varför väljer han den för att gestalta en groda? } \\
\text { Why does he choose this to represent a frog? } \\
\text { [points on the screen with a paused film, on the actor's spread hand] }\end{array}$ \\
\hline $\begin{array}{l}\text { Swedish } \\
\text { English } \\
\text { SSL } \\
\text { Comment/ } \\
\text { description }\end{array}$ & [places two spread hands in front of the body, laughs------------] \\
\hline $\begin{array}{l}\text { Swedish } \\
\text { English } \\
\text { SSL } \\
\text { Comment/ } \\
\text { description }\end{array}$ & $\begin{array}{l}\text { ja... grodfötter. } \\
\text { yes ... frog feet. } \\
\text { [continues]----------- }\end{array}$ \\
\hline $\begin{array}{l}\text { Swedish } \\
\text { English } \\
\text { SSL } \\
\text { Comment/ } \\
\text { description }\end{array}$ & $\begin{array}{l}\text { Grodans fötter har den här formen. } \\
\text { The frog's feet have this shape. } \\
\text { [continues]---[points on the one spread hand with index finger] }\end{array}$ \\
\hline $\begin{array}{l}\text { Swedish } \\
\text { English } \\
\text { SSL } \\
\text { Comment/ } \\
\text { description }\end{array}$ & $\begin{array}{l}\text { Det är också typiskt att när man väljer att gestalta någonting så väljer man en form } \\
\text { It's also typical that when you choose to represent something, you choose a form }\end{array}$ \\
\hline
\end{tabular}




\begin{tabular}{|c|c|}
\hline $\begin{array}{l}\text { Swedish } \\
\text { English } \\
\text { SSL } \\
\text { Comment/ } \\
\text { description }\end{array}$ & $\begin{array}{l}\text { som på nåt sätt kan appellera till det vi upplever är den riktiga formen i verkligheten. } \\
\text { that in some way can appeal to what we experience as the actual form in reality. }\end{array}$ \\
\hline & {$[\ldots]$} \\
\hline $\begin{array}{l}\text { Swedish } \\
\text { English } \\
\text { SSL } \\
\text { Comment/ } \\
\text { description } \\
\end{array}$ & $\begin{array}{l}\text { Det här sättet att välja när man visar det är något teckenspråket har } \\
\text { This way to choose when you show it's something sign language has }\end{array}$ \\
\hline $\begin{array}{l}\text { Swedish } \\
\text { English } \\
\text { SSL } \\
\text { Comment/ } \\
\text { description }\end{array}$ & $\begin{array}{l}\text { som kallas teckenspråkets ikonicitet. } \\
\text { that's called sign language iconicity. }\end{array}$ \\
\hline $\begin{array}{l}\text { Swedish } \\
\text { English } \\
\text { SSL } \\
\text { Comment/ } \\
\text { description } \\
\end{array}$ & $\begin{array}{l}\text { Vad betyder det ordet? } \\
\text { What does that word mean? }\end{array}$ \\
\hline $\begin{array}{l}\text { Swedish } \\
\text { English } \\
\text { SSL } \\
\text { Comment/ } \\
\text { description }\end{array}$ & $\begin{array}{l}\text { Ikonicitet. } \\
\text { Iconicity. }\end{array}$ \\
\hline $\begin{array}{l}\text { Swedish } \\
\text { English } \\
\text { SSL } \\
\text { Comment/ } \\
\text { description } \\
\end{array}$ & $\begin{array}{l}\text { Någon som vet vad en ikon är? } \\
\text { Does anyone know what an icon is? }\end{array}$ \\
\hline $\begin{array}{l}\text { Swedish } \\
\text { English } \\
\text { SSL } \\
\text { Comment/ } \\
\text { description }\end{array}$ & $\begin{array}{l}\text { Vad är en ikon? } \\
\text { What is an icon? }\end{array}$ \\
\hline $\begin{array}{l}\text { Swedish } \\
\text { English } \\
\text { SSL } \\
\text { Comment/ } \\
\text { description }\end{array}$ & $\begin{array}{l}\text { En symbol för någonting och det är en bild. } \\
\text { A symbol for something and that's a picture. }\end{array}$ \\
\hline $\begin{array}{l}\text { Swedish } \\
\text { English } \\
\text { SSL } \\
\text { Comment/ } \\
\text { description }\end{array}$ & $\begin{array}{l}\text { Det är en symbol för något och det är bildlikt och det kan man göra med händerna. } \\
\text { It's a symbol for something and it's similar to a picture and you can do it with your hands. }\end{array}$ \\
\hline $\begin{array}{l}\text { Swedish } \\
\text { English } \\
\text { SSL } \\
\text { Comment/ } \\
\text { description } \\
\end{array}$ & $\begin{array}{l}\text { Det utnyttjar man med teckenspråk, man kan inte göra det så bra med rösten, } \\
\text { It's used in sign language-you cannot do it as well with the voice, }\end{array}$ \\
\hline $\begin{array}{l}\text { Swedish } \\
\text { English } \\
\text { SSL } \\
\text { Comment/ } \\
\text { description } \\
\end{array}$ & $\begin{array}{l}\text { alltså har vi inte den möjligheten i talspråk på samma sätt. } \\
\text { so we don't have this ability in spoken language in the same way. }\end{array}$ \\
\hline $\begin{array}{l}\text { Swedish } \\
\text { English } \\
\text { SSL } \\
\text { Comment/ } \\
\text { description }\end{array}$ & $\begin{array}{l}\text { Så teckenspråkets möjlighet till ikonicitet avspeglas i hur vi väljer handformer } \\
\text { So sign language's capacity for iconicity is reflected in how we choose hand shapes } \\
\text { [points towards the screen with the paused film and moves her hand in a circle around the actor's hand] }\end{array}$ \\
\hline $\begin{array}{l}\text { Swedish } \\
\text { English } \\
\text { SSL } \\
\text { Comment/ } \\
\text { description }\end{array}$ & $\begin{array}{l}\text { då vi får välja fritt, } \\
\text { when we can choose freely, }\end{array}$ \\
\hline $\begin{array}{l}\text { Swedish } \\
\text { English } \\
\text { SSL } \\
\text { Comment/ }\end{array}$ & $\begin{array}{l}\text { Då får man välja en sånhär handform för en grodfot, } \\
\text { Then you can choose such a hand shape for a frogs'foot, } \\
\text { [places two spread hands in front of the body and gesticulates around with them] }\end{array}$ \\
\hline
\end{tabular}




\begin{tabular}{|c|l|} 
description & \\
\hline Swedish & och såhär eller ännu mindre om man pratar om ett djur som har en typisk liten tass. \\
English & and like this, or even smaller if you talk about an animal that has a typical little paw. \\
SSL & [cowers and uses the bent hand in front of the body and then changes to index fingers] \\
Comment/ &
\end{tabular}

\section{ACKNOWLEDGMENTS}

The author wishes to thank Kristina Svartholm, Stockholm University, for comments on previous version of this paper.

\section{REFERENCES}

[1] Almqvist, I. (2013). Tolk- och översättarinstitutet - ett institut i förändring [Interpreter and translation institute - an institute in change]. In Språkrådet (ed.), Från ett språk till ett annat. Om översättning och tolkning [From one language to another. About translation and interpretation]. Språkrådets skrifter 15. Stockholm: Norstedts, 57-65.

[2] Balkstam, E. (2018). Fonologisk utveckling i det svenska teckenspråket hos hörande andraspråksinlärare. Identifiering av aspekter, tecken och en- och tvåhandstecken [Phonological development in hearing second language learners of Swedish Sign Language. Identifying parameters, signs and one- and two-handed signs]. MA-thesis. Department of Linguistics, Stockholm University, Sweden.

[3] Bel, A., Ortells, M. \& Morgan, G. (2015). Reference control in the narratives of adult sign language learners. International Journal of Bilingualism 19.5, 608-624. DOI: 10.1177/1367006914527186.

[4] Chen Pichler, D. \& Koulidobrova, E. (2015). Acquisition of Sign Language as a second language. In M. Marschark \& P.E. Spencer (eds.), The Oxford Handbook of Deaf Studies in Language. Oxford: Oxford Handbooks Online. DOI: 10.1093/oxfordhb/9780190241414.013.14.

[5] Ferrara, L. \& Nilsson, A-L. (2017). Describing spatial layouts as an L2M2 signed language learner. Sign Language \& Linguistics 20.1, 1-26. DOI: 10.1075/sll.20.1.01fer.

[6] Hauser, P. C., Paludneviciene, R., Supalla, T. \& Bavelier, D. (2008). American sign language-sentence reproduction test: development and implications". In R. M. D. Quadros (ed.), Sign Language: Spinning and Unraveling the Past, Present and Future. Petropolis: Editora Arara Azul, 160-172.

[7] Holmström, I. (2018a). Undervisning i svenskt teckenspråk som andraspråk. En rapport från UTL2-projektet [Teaching Swedish Sign Language as second language. A report from the project UTL2]. Forskning om teckenspråk XXVI. Department of Linguistics, Stockholm University, Sweden.

[8] Holmström, I. (2018b). Teaching Swedish Sign Language as second language to interpreter students. In S. Coster (ed), Proceedings from the Nordic Seminar. Umeå, Sweden, 23-25 February 2018, 80-91.

[9] McAteer, M. (2013). Action Research in Education. London: SAGE Publications Ltd.

[10] Medgyes, P. (2017). The Non-Native Teacher (3rd edn.). Scotland, UK: Swan Communication.

[11] Metzger, M. (1995). Constructed dialogue and constructed action in American Sign Language. In C. Lucas (ed.), Sociolinguistics in Deaf Communities. Washington DC: Gallaudet University Press, 255-271.

[12] Ortega, G. \& Morgan, G. (2015). Input processing at first exposure to a sign language. Second Language Research 31.4, 443463. DOI: $10.1177 / 0267658315576822$.

[13] Quinto-Pozos, D. (2011). Teaching American Sign Language to hearing adult learners. Annual Review of Applied Linguistics 31, 137-158. Doi: 10.1017/S0267190511000195.

[14] Richards, J. \& Rodgers, T. (2001). Approaches and Methods in Language Teaching. Cambridge: Cambridge University Press.

[15] Riordan, E. (2018). Language for teaching purposes. Bilingual classroom discourse and the non-native speaker language teacher. Cham: Springer International Publishing. DOI: 10.1007/978-3-319-71005-1.

[16] Schönström, K. \& Holmström, I. (2017). Elicited imitation tasks (EITs) as a tool for measuring sign language proficiency in L1 and L2 signers. Paper presentation at ALTE 6th Conference, Learning and Assessment: Making the Connections. Bologna, Italy, 3-5 May.

[17] Schönström, K. \& Mesch, J. (2017). Dataset. The project 'From speech to sign - learning Swedish Sign Language as a second language'. Department of Linguistics, Stockholm University, Sweden.

[18] Skolverket. (2014). Research for Classrooms. Scientific Knowledge and Proven Experience in Practice. Stockholm: Skolverket.

[19] Taub, S. F. (2012). Iconicity and metaphor. In R. Pfau, M. Steinbach \& B. Woll (eds.), Sign language. An International Handbook. Berlin/Boston: De Gruyter Mouton, 388-411.

[20] Woll, B. (2013). Second language acquisition of sign language. The Encyclopedia of Applied Linguistics. DOI: 10.1002/9781405198431.wbeal1050.

Ingela Holmström, Assistant professor and lecturer at the Department of Linguistics, Stockholm University, Sweden. She get her $\mathrm{PhD}$ in Education at Örebro University 2013 and her research is directed towards communication issues in interaction between deaf, hard-of-hearing and hearing people both in and outside school contexts. She has a special interest in bi- and multilingualism and also conducts research on teaching Swedish Sign Language as a second language for hearing students. In addition, Dr Holmström has a background as a teacher for the deaf in upper secondary schools in Sweden. 